\title{
PENGARUH PENAMBAHAN ENZIM PAPAIN TERHADAP KARAKTERISTIK FISIK, KIMIA, DAN ORGANOLEPTIK SUSU KEDELAI (KAJIAN JENIS KEDELAI DAN KONSENTRASI ENZIM PAPAIN)
}

\section{The Effect of Papain Enzyme Addition on the Physical, Chemical and Organoleptic Characteristic of Soy Milk (Study of Soybean Type and Enzyme Papain Concentration)}

\author{
Mar'atus Soleha*, Jaya Mahar Maligan, Yunianta \\ Jurusan Teknologi Hasil Pertanian, FTP Universitas Brawijaya Malang \\ Jl. Veteran, Malang 65145 \\ *Penulis Korespondensasi, Email: maratus_soleha678@yahoo.com
}

\begin{abstract}
ABSTRAK
Susu kedelai sering digunakan sebagai alternatif pengganti susu sapi, karena memiliki kandungan nutrisi yang tidak kalah dengan susu sapi serta harganya lebih terjangkau. Kedelai memiliki kandungan antigizi yang dapat mengganggu tercernanya protein di dalam tubuh. Penambahan enzim papain diharapkan mampu menghidrolisis protein dalam kedelai menjadi asam amino sederhana sehingga mudah dicerna oleh tubuh. Penelitian ini menggunakan rancangan percobaan Nested Design dengan 2 faktor. Faktor I jenis kedelai (kedelai sayur, kedelai hitam, kedelai kuning), faktor II konsentrasi enzim papain (100 ppm, 200 ppm, 300 ppm). Berdasarkan karakteristik kimia dan fisik, susu kedelai terbaik adalah perlakuan jenis susu kedelai hitam dengan konsentrasi enzim papain $300 \mathrm{ppm}$ (K2P3). Nilai protein terlarut 0,34\%, N Amino $0,02 \%$, pH 6,6; viskositas 5,00; kecerahan (L) 77,1; kehijauan (a) -3.4 dan kekuningan (b) 14.3. Sedangkan perlakuan terbaik berdasarkan karakteristik organoleptik diperoleh pada perlakuan jenis kedelai kuning dengan konsentrasi enzim papain 200 ppm
\end{abstract}

Kata Kunci : Enzim papain, Hidrolisis enzimatis, Kedelai, Susu kedelai

\begin{abstract}
Soy milk is often used for subtitute alternative product of cow's milk. It has nutritional content as good as cow's milk, yet cheaper than cow's milk product. Soybean contains anti - nutritional that can interfere protein digestion in body. Thus, it needs to be removed. The method used was Nested Design experiment with 2 factors. The first factor is soybean type (vegetable soybean, black soybean, yellow soybean). The second factor is concentration of papain enzyme (100 ppm, 200 ppm, 300 ppm). Based on chemical and physical characteristics, the best soybean milk is black soybean milk using 300 ppm of papain enzyme (K2P3) with dissolved protein value 0,34\%; N Amino 0,02\%; pH 6,6; viscocity 5,00; brightness (L) 77,1; greenish (a) -3,4; yellowish (b) 14,3. While the best treatment based on organoleptic characteristic is obtained from yellow soybean with 200 ppm of papain enzyme.
\end{abstract}

Keywords: Enzymatic Hydrolisis, Papain enzyme, Soybean, Soy Milk 


\section{PENDAHULUAN}

Kedelai merupakan sumber protein nabati yang mempunyai mutu atau nilai biologi tertinggi (Almatsier, 2009). Indonesia termasuk dalam 10 negara terbesar dunia (2007-2011) sebagai pengimpor kedelai dengan rata-rata volume sebesar 1.712 ton per tahun (Kementerian Pertanian, 2015). Produk susu kedelai seringkali digunakan sebagai pengganti susu sapi, karena kandungan proteinnya yang tidak jauh berbeda dengan susu sapi. Susu kedelai tidak mengandung laktosa seperti pada susu sapi, sehingga sangat baik bagi penderita lactose intolerance. Golongan vegetarian juga memanfaatkan produk olahan kedelai ini sebagai salah satu produk untuk memenuhi kebutuhan protein yang dianjurkan. Kedelai sebagai bahan baku utama pembuatan susu kedelai memiliki kandungan antigizi. Senyawa tersebut dapat mengganggu tercernanya protein di dalam tubuh.

Upaya untuk mengatasi hal tersebut adalah dengan melakukan penambahan enzim papain pada susu kedelai. Tujuan dilakukannya penambahan enzim papain tersebut adalah untuk membuat produk susu kedelai dengan harapan daya cerna susu kedelai lebih tinggi. Dimana, dengan penambahan enzim papain diharapkan protein-protein dalam susu kedelai dapat terhidrolisis menjadi asam amino yang lebih sederhana, sehingga tubuh dapat mencernanya dengan lebih mudah. Enzim papain memiliki gugus fungsional sulfhidril dan mampu menghidrolisis ikatan peptida pada asam amino lisin dan glisin. Suhu optimum papain berkisar antara $50^{\circ} \mathrm{C}-65^{\circ} \mathrm{C}$, dan $\mathrm{pH}$ optimum antara 5-7 (Sumartha, 1990).

Berdasarkan uraian di atas maka dilakukan penelitian pengaruh penambahan enzim papain terhadap karakteristik kimia, fisik dan organoleptik susu kedelai (kajian jenis kedelai dan konsentrasi enzim papain) untuk mengetahui pengaruh penambahan enzim papain terhadap sifat fisik, kimia dan organoleptik susu kedelai dengan mengkaji jenis kedelai terbaik dan konsentrasi enzim papain terbaik untuk menghasilkan susu kedelai yang diinginkan dan dapat diterima.

\section{BAHAN DAN METODE}

\section{Bahan}

Bahan baku yang digunakan pada penelitian ini adalah kedelai edamame segar (Yulia Frozen Food), kedelai hitam (Balitkabi Malang), dan kedelai kuning (Balitkabi Malang), Enzim papain kode E.C.3.4.22.2 produksi AG Switzerland, gula, garam dan Carboxy Methyl Cellulose. Sedangkan bahan untuk analisis antara lain larutan protein standar, pereaksi biuret, asam tri kloro asetat, aquades, dietil eter pro analysis, aquades, kalium oksalat jenuh, indikator Phenolptalin, $\mathrm{NaOH}$, dan formaldehid pro analysis.

\section{Alat}

Alat yang digunakan dalam pembuatan sari kedelai adalah timbangan analitik (Ohaus), spatula, kain saring, termometer, baskom, blender (Miyako), kompor (Rinnai), dan panci enamel. Alat yang digunakan untuk hidrolisis enzimatis pada susu kedelai adalah oven listrik (Memmert), timbangan analitik (Denver M 310 USA), shaker waterbath (Memmert), magnetic stirrer (MS-HPro GSA), dan glassware.

Sedangkan alat yang digunakan untuk analisis antara lain sentrifuge (Hettich Zentrifugen EBA 20), spektrofotometer (Spectro 20D Plus), vortex (Turbo Mixer LW Scientific), tabung sentrifuge (Biologix), buret (Duran), color reader (Konica Minolta), botol kaca, dan viskometer dan cup plastik kecil.

\section{Desain penelitian}

Metode penelitian yang digunakan adalah Nested Design dengan 2 faktor. Faktor I jenis kedelai $(\mathrm{K})$ terdiri atas kedelai edamame, kedelai hitam dan kedelai kuning. Faktor II konsentrasi 
enzim papain (P) terdiri atas 3 level (100 ppm, 200 ppm, 300 ppm) diulang sebanyak 3 kali sehingga diperoleh 27 percobaan. Data yang diperoleh dianalisis secara statistik dengan Analisis Varian (ANOVA) dan uji lanjut BNT (Beda Nyata Terkecil) taraf 5\%. Uji organoleptik dianalisis dengan Friedman test. Pemilihan perlakuan terbaik dilakukan dengan multiple atribute.

\section{Tahapan Penelitian}

Tahapan penelitian yang dilakukan terbagi atas 2 tahap. Tahap pertama yaitu pembuatan susu kedelai dengan menimbang tiga jenis kedelai (edamame, hitam, kuning) mentah terlebih dahulu, masing-masing ditimbang sebanyak 100 gram. Setelah itu dilakukan sortasi, kedelai mentah yang telah disortasi dicuci dengan air bersih. Kemudian direndam dengan larutan $\mathrm{NaHCO}_{3}$ sebanyak $0,5 \%$ selama 8 jam. Setelah 8 jam, air rendaman dibuang, kedelai ditiriskan dan ditambahkan air baru, selanjutnya dilakukan pemanasan selama 30 menit hingga mendidih. Kedelai yang sudah mendidih, diremas-remas dan dicuci dengan air beberapa kali. Kedelai yang sudah bersih digiling dengan menggunakan blender dan ditambahkan air mendidih. Bubur encer kedelai disaring dengan menggunakan kain saring, filtratnya diambil. Tahap kedua yaitu proses hidrolisis protein susu kedelai dengan enzim papain yaitu masing-masing susu kedelai diambil sebanyak $50 \mathrm{ml}$, kemudian ditambahkan enzim papain sesuai dengan perlakuan (konsentrasi 100 ppm, 200 ppm, dan 300 ppm). Setelah itu, dihidrolisis dengan enzim papain pada suhu 60 ${ }^{\circ} \mathrm{C}$ selama 2 jam, kemudian diinaktivasi enzim pada suhu tinggi $\left(105^{\circ} \mathrm{C}\right)$ selama 10 menit. Setelah proses inaktivasi, dilakukan penambahan gula 7\%, garam 0,1\% dan CMC 100 ppm lalu dilakukan pengadukan. Kemudian disimpan dalam botol streril.

\section{Prosedur Analisis}

Analisis kimia untuk protein terlarut dilakukan dengan menggunakan metode biuret (Sudarmadji et al., 1997), kadar $\mathrm{N}$ amino dengan menggunakan metode titrasi formol (Sudarmadji et al., 1997), pH dilakukan dengan pH meter, uji fisik viskositas dengan alat viskometer (Yuwono dan Susanto, 2001), uji fisik warna dengan menggunakan color reader (Yuwono dan Susanto, 2001). Uji organoleptik dilakukan dengan uji hedonik.

\section{Kadar Protein terlarut}

\section{HASIL DAN PEMBAHASAN}

Pengaruh jenis kedelai dan konsentrasi enzim papain terhadap rerata kadar protein terlarut susu kedelai dapat dilihat pada Gambar 1. Gambar 1 menunjukkan bahwa jenis kedelai edamame dengan penambahan enzim sebesar $100 \mathrm{ppm}$ memberikan nilai protein terlarut tertinggi dan jenis kedelai hitam dengan penambahan enzim sebesar $300 \mathrm{ppm}$ memberikan niai protein terlarut terendah. Berdasarkan hasil analisis sidik ragam, jenis kedelai dan konsentrasi enzim berpengaruh nyata $(\alpha=0,05)$ terhadap kadar protein terlarut.

Tingginya kadar protein terlarut pada kedelai edamame, kemungkinan disebabkan oleh tingginya kadar glisin dalam kedelai edamame. Maryam (2007), menyatakan bahwa protein yang terdapat dalam kedelai berupa legumelin dan glisin. Legumelin merupakan kelompok albumin yang bersifat larut dalam air sedangkan glisin merupakan kelompok globulin yang bersifat tidak larut dalam air. Kedelai hitam (Mallika) memiliki kandungan glisin sebesar 2,52 mg/gr, kedelai kuning (grobogan) memiliki kandungan glisin sebesar 3,15 mg/gr (Nurrahman, 2015) dan kedelai edamame memiliki kandungan glisin sebesar $7,17 \mathrm{mg} / \mathrm{gr}$ (Song et al., 2003). Berdasarkan hasil penelitian, diketahui bahwa ketiga konsentrasi enzim tersebut belum bisa menaikkan kadar protein terlarut secara signifikan. Menurut Wijaya et al. (2015), semakin tinggi konsentrasi enzim yang ditambahkan, semakin banyak ikatan peptida yang terhidrolisis maka jumlah ikatan peptida yang terhitung sebagai protein terlarut semakin rendah. 


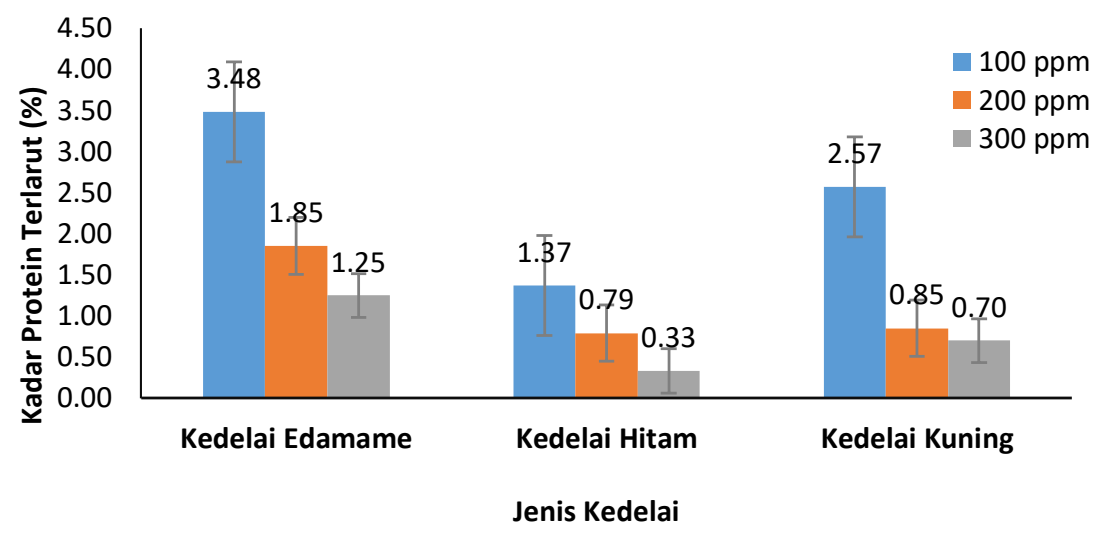

Gambar 1. Rerata Kadar Protein Terlarut Susu Kedelai akibat Perlakuan Tiga Jenis Kedelai dan Konsentrasi Enzim Papain

\section{Kadar N Amino}

Pengaruh jenis kedelai dan konsentrasi enzim papain terhadap rerata kadar protein terlarut susu kedelai dapat dilihat pada Gambar 2.

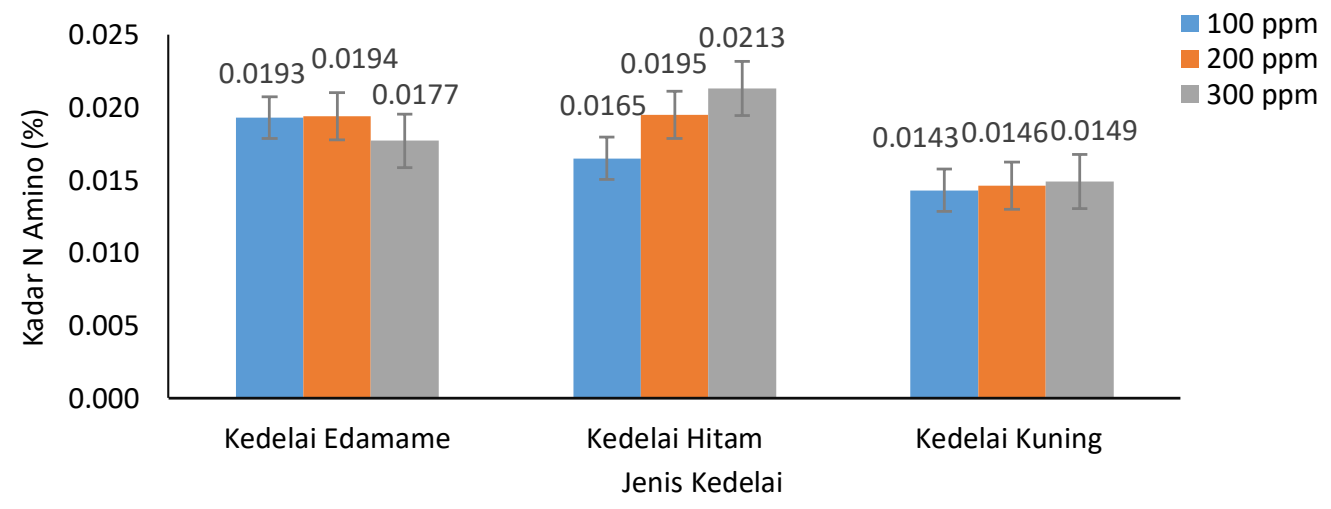

Gambar 2. Rerata Kadar N Amino Susu Kedelai akibat Perlakuan Tiga Jenis Kedelai dan Konsentrasi Enzim Papain

Berdasarkan Gambar 2, diketahui bahwa perlakuan jenis kedelai hitam dengan konsentrasi enzim papain 300 ppm memberikan nilai $\mathrm{N}$ amino tertinggi dan perlakuan jenis kedelai edamame dengan penambahan enzim papain 100 ppm memberikan nilai $\mathrm{N}$ amino terendah. Berdasarkan hasil analisis sidik ragam, jenis kedelai memberikan pengaruh nyata $(\alpha=0,05)$ dan konsentrasi enzim tidak memberikan pengaruh nyata terhadap kadar $\mathrm{N}$ amino. Tingginya kandungan $\mathrm{N}$ amino susu kedelai edamame diduga disebabkan oleh perbedaan kandungan protein yang terdapat dalam setiap jenis kedelai tidak sama. Sehingga kadar $\mathrm{N}$ amino yang terhidrolisis akibat proses hidrolisis enzimatis oleh enzim papain berbeda. Dimana, kandungan protein kedelai hitam sebesar 45,40\% bk (Ginting dan Adjie, 2007), kandungan protein kedelai kuning sebesar 39,99\% bk (Yulifianti et al., 2015) dan kandungan protein kedelai edamame sebesar 11,22 g/100 g (11.22\%) (USDA, 2016). 


\section{Derajat Keasaman $(\mathrm{pH})$}

Pengaruh jenis kedelai dan konsentrasi enzim papain terhadap rerata kadar protein terlarut susu kedelai dapat dilihat pada Gambar 3.

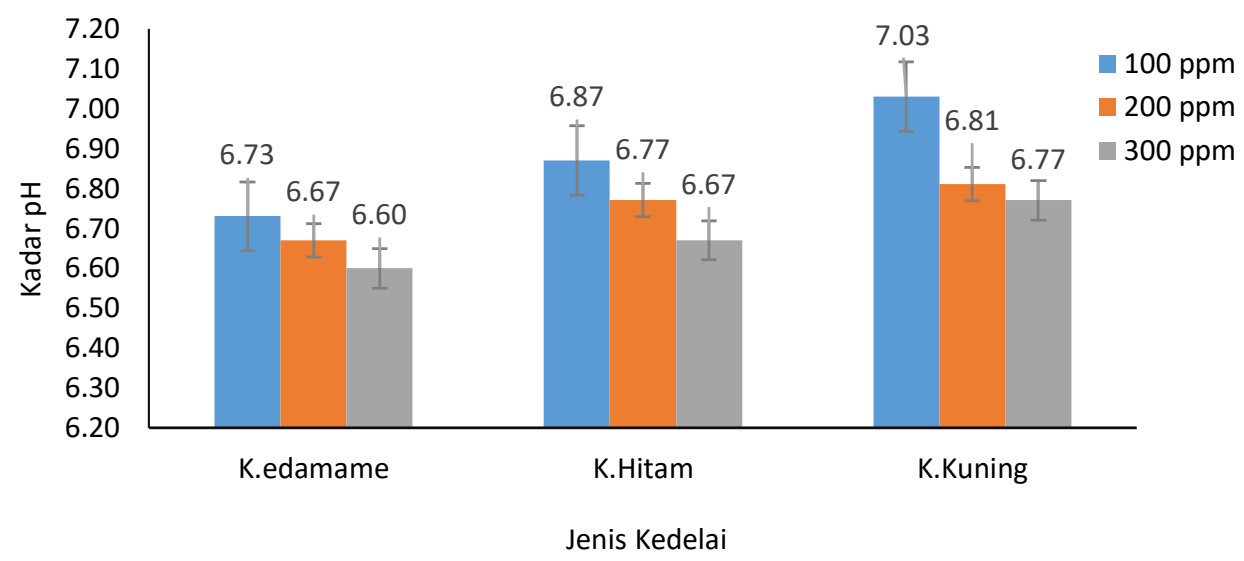

Gambar 3. Rerata Kadar pH Susu Kedelai akibat Perlakuan Tiga Jenis Kedelai dan Konsentrasi Enzim Papain

Gambar 3 menunjukkan bahwa $\mathrm{pH}$ tertinggi diperoleh dari perlakuan jenis kedelai kuning dengan konsentrasi enzim papain $100 \mathrm{ppm}$ sedangkan $\mathrm{pH}$ terendah diperoleh dari perlakuan jenis kedelai hitam dengan konsentrasi enzim papain 300 ppm. Gambar 3 juga menunjukkan bahwa konsentrasi enzim papain yang ditambahkan berbanding terbalik dengan kadar $\mathrm{pH}$ susu kedelai. Semakin tinggi konsentrasi enzim, maka kadar pH susu kedelai juga semakin menurun.

Berdasarkan hasil analisis sidik ragam, diketahui bahwa jenis dan konsentrasi enzim berpengaruh nyata terhadap kadar $\mathrm{pH}$. Perbedaan kadar $\mathrm{pH}$ susu kedelai diduga karena bahan baku kedelai yang digunakan juga memiliki kadar $\mathrm{pH}$ yang beragam yaitu 6,47 untuk kedelai edamame dan 6,60 untuk kedelai hitam dan kedelai kuning. Keragaman kadar pH bahan baku biji kedelai tersebut mempengaruhi kadar $\mathrm{pH}$ setelah dilakukannya perlakuan penambahan enzim papain. Dimana, $\mathrm{pH}$ yang didapatkan lebih tinggi dibandingkan sebelum adanya perlakuan. Dimana, dengan terjadinya perubahan $\mathrm{pH}$ bahan baku dan $\mathrm{pH}$ produk susu kedelai yang sudah diberi perlakuan penambahan enzim papain. Hal tersebut mengisyaratkan bahwa $\mathrm{pH}$ susu kedelai setelah diberi perlakuan menjadi semakin tinggi dan meningkatnya kadar $\mathrm{pH}$ tersebut menunjukkan bahwa telah terjadi proses hidrolisis enzimatis didalamnya. Menurut Deliana (2008) dalam Yusrina (2016), enzim proteolitik akan menyebabkan degradasi protein menjadi asam amino, sehingga jumlah nitrogen terlarut meningkat. Degradasi protein ini juga menyebabkan peningkatan $\mathrm{pH}$.

Berdasarkan pada Gambar 3, dapat diketahui bahwa $\mathrm{pH}$ susu kedelai mengalami penurunan seiring dengan peningkatan konsentrasi enzim papain yang ditambahkan. Menurut Nielsen (2010), larutan protein yang terhidrolisis akan mengalami penurunan $\mathrm{pH}$, karena pada saat enzim protease memecah ikatan peptida, gugus karboksilat dilepaskan dan akan dibebaskan sejumlah ion hidrogen. Menurut Lehninger (1994), asam amino penyusun protein merupakan turunan dari asam karboksilat yang satu atom hidrogennya diganti dengan gugus amino $\left(-\mathrm{NH}_{2}\right)$. Gugus asam karboksilat menyebabkan sifat asam dan gugus amino menyebabkan sifat basa sehingga asam amino bersifat amfoter

\section{Viskositas}

Pengaruh jenis kedelai dan konsentrasi enzim papain terhadap rerata kadar protein terlarut susu kedelai dapat dilihat pada Gambar 4. Gambar 4 menunjukkan nilai viskositas tertinggi 
terdapat pada perlakuan jenis kedelai edamame dengan penambahan enzim sebesar 200 ppm. Sedangkan perlakuan jenis kedelai hitam dengan penambahan enzim papain sebesar 300 ppm memberikan nilai viskositas yang terendah. Berdasarkan hasil analisis sidik ragam diketahui bahwa jenis kedelai memberikan pengaruh nyata $(\alpha=0.05)$, sedangkan konsentrasi enzim tidak memberikan pengaruh nyata terhadap kadar viskositas. Perbedaan kadar viskositas susu kedelai yang dihasilkan kemungkinan dikarenakan oleh perbedaan varietas yang digunakan. Dimana, setiap varietas memiliki kandungan protein yang berbeda, sehingga akan mempengaruhi nilai viskositas yang terhitung. Menurut Ginting (2002), Varietas kedelai dan cara pengolahan berpengaruh nyata terhadap kadar protein, total padatan terlarut (TPT), rendemen dan viskositas sari kedelai.

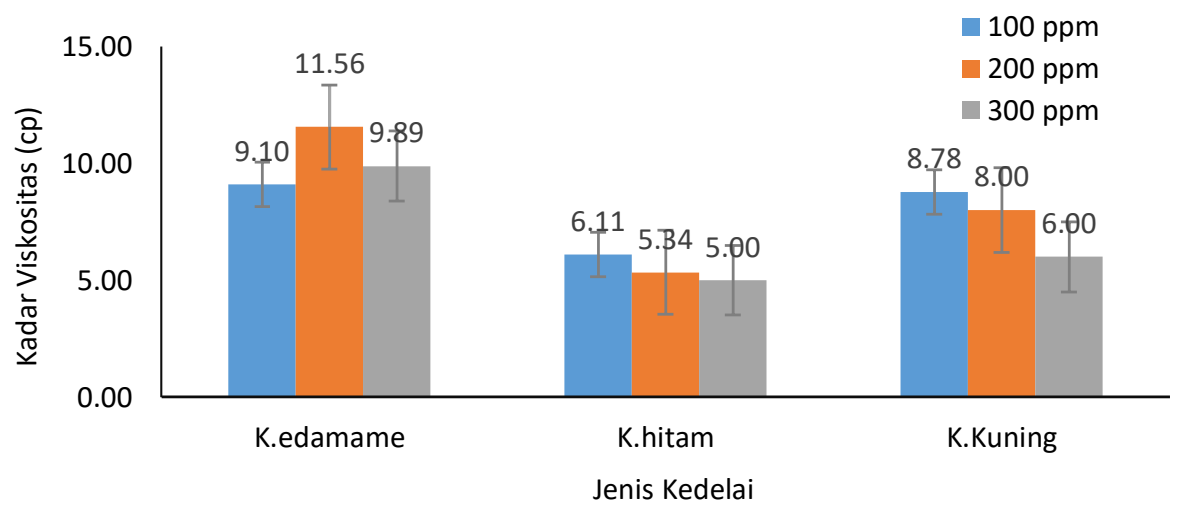

Gambar 4. Rerata Kadar Viskositas Susu Kedelai akibat Perlakuan Tiga Jenis Kedelai dan Konsentrasi Enzim Papain

\section{Kecerahan ( $\left.L^{*}\right)$}

Rerata tingkat kecerahan $\left(L^{*}\right)$ susu kedelai akibat perlakuan jenis kedelai dan konsentrasi enzim papain dapat dilihat pada Gambar 5. Gambar 5 menunjukkan bahwa rerata kecerahan susu kedelai edamame memberikan nilai terendah, sedangkan rerata kecerahan susu kedelai kuning memberikan nilai tertinggi. Berdasarkan hasil analisis sidik ragam, diketahui bahwa jenis kedelai dan konsentrasi enzim berpengaruh nyata $(\alpha=0.05)$ terhadap kecerahan $(L)$.

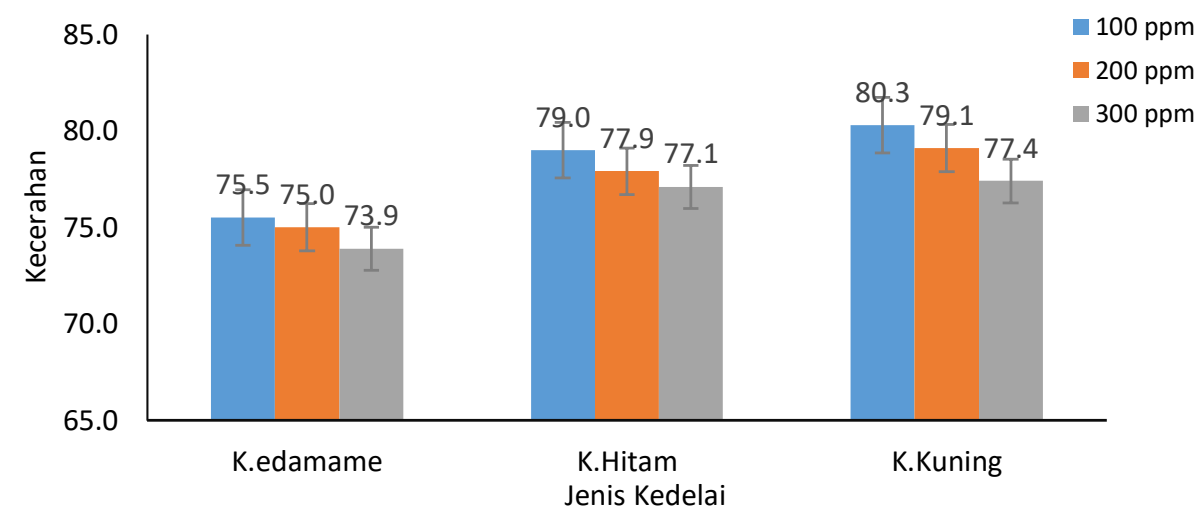

Gambar 5. Rerata Tingkat Kecerahan (L) Susu Kedelai akibat Perlakuan Tiga Jenis Kedelai dan Konsentrasi Enzim Papain 
Tingginya nilai kecerahan susu kedelai kuning disebabkan oleh warna susu kedelai kuning yang dihasilkan adalah warna kuning cerah, hal ini juga terjadi pada susu kedelai hitam. Pada penelitian ini saat proses pengolahan susu kedelai, biji kedelai yang telah terendam dikupas kulit arinya. Sehingga susu kedelai yang dihasilkan lebih cerah (lebih putih) dan tidak mengikuti warna kulit ari biji kedelai. Sedangkan pada edamame, susu kedelai edamame yang dihasilkan memiliki kecerahan yang sangat rendah kemungkinan dikarenakan warna hijau pada kedelai edamame yang masih melekat pada biji kedelai edamame (meskipun sudah dibuang kulit arinya) pada saat pengolahan susu kedelai. Menurut Sofyanti (2007), pengupasan kulit biji kedelai bertujuan untuk mengurangi jumlah serat atau bahan-bahan yang tidak larut dalam air yang dapat menghambat pada saat proses ekstraksi dan dapat memperbaiki warna dari serat kedelai yang dihasilkan.

Gambar 5, menunjukkan bahwa semakin tinggi konsentrasi enzim papain yang diberikan, maka rerata kecerahan produk akan semakin menurun. Penurunan nilai kecerahan tersebut diduga karena semakin tinggi penambahan konsentrasi enzim proteolitik, maka semakin banyak gugus amino yang terbentuk. Witono et al. (2007) yang menyatakan bahwa semakin besar konsentrasi protease biduri, maka nilai produk Maillard hidrolisat protein kedelai yang dihasilkan semakin tinggi. Witono et al. (2007) juga menambahkan bahwa semakin banyak konsentrasi enzim, reaksi maillard yang terjadi semakin intensif.

\section{Kehijauan $\left(a^{*}\right)$}

Dimana, nilai kehijauan tertinggi terdapat pada perlakuan jenis kedelai edamame dengan penambahan enzim sebesar 100 ppm. Sedangkan perlakuan jenis kedelai kuning dengan penambahan enzim papain sebesar 100 ppm memberikan nilai kehijauan yang terendah. Berdasarkan hasil analisis sidik ragam, diketahui bahwa jenis kedelai berpengaruh nyata $(\alpha=0,05)$ dan konsentrasi enzim tidak berpengaruh nyata terhadap kehijauan susu kedelai. Tingginya nilai kehijauan pada kedelai edamame disebabkan oleh karena bahan baku kedelai edamame memang memiliki warna hijau. Hal tersebut dikarenakan edamame memang memiliki kandungan pigmen klorofil.

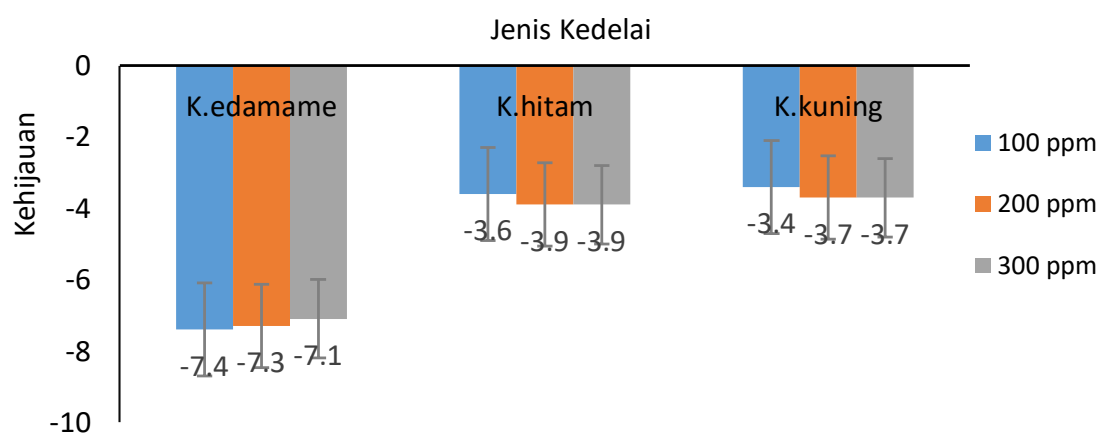

Gambar 6. Rerata Tingkat Kehijauan (a) Susu Kedelai Akibat Perlakuan Tiga Jenis Kedelai dan Konsentrasi Enzim Papain

Klorofil yaitu pigmen pemberi warna hijau pada tumbuhan, alga dan bakteri fotosintetik. Senyawa ini berperan dalam fotosintesis tumbuhan dengan menyerap dan mengubah tenaga cahaya matahari menjadi tenaga kimia. Pada tanaman tingkat tinggi ada dua macam klorofil yaitu klorofil-a yang berwarna hijau tua dan klorofil-b yang berwarna hijau muda (Hasibuan, 2011). Berdasarkan pada Grafik CIELAB, adanya nilai kehijauan pada susu kedelai kuning dan hitam kemungkinan dikarenakan nilai $-a$ yang terdeteksi mendekati nilai $+b$ sehingga menunjukkan warna hijau kekuningan. 


\section{Kekuningan $\left(b^{\star}\right)$}

Gambar 7 menunjukkan rerata tingkat kekuningan akibat perlakuan 3 jenis kedelai dengan konsentrasi enzim papain yang berbeda. Dimana, nilai kekuningan tertinggi terdapat pada perlakuan jenis kedelai edamame dengan penambahan enzim sebesar 200 ppm. Sedangkan perlakuan jenis kedelai kuning dengan penambahan enzim papain sebesar 300 ppm memberikan nilai kekuningan yang terendah. Berdasarkan hasil analisis sidik ragam, diketahui bahwa jenis kedelai berpengaruh nyata $(\alpha=0.05)$ dan konsentrasi enzim tidak berpengaruh nyata terhadap kekuningan susu kedelai.

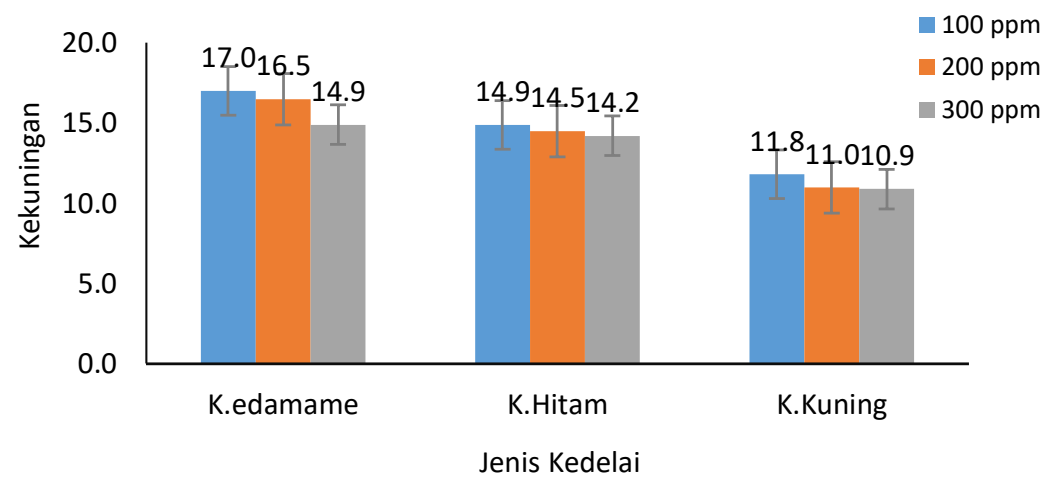

Gambar 7. Rerata Tingkat Kekuningan (b) Susu Kedelai akibat Perlakuan Tiga Jenis Kedelai dan Konsentrasi Enzim Papain

Rendahnya nilai kekuningan pada kedelai kuning tersebut kemungkinan dikarenakan terjadinya rekasi Maillard. Agustawa (2012), menyebutkan bahwa reaksi ini dapat terjadi bila gula pereduksi bereaksi dengan senyawa yang memiliki gugus $\mathrm{NH}_{2}$ (protein, asam amino, peptida, dan ammonium) dan juga apabila bahan dipanaskan atau didehidrasi sehingga akan menimbulkan warna kecoklatan pada produk. Warna kecoklatan tersebutlah yang menyebabkan intensitas nilai kekuningan menjadi menurun.

\section{Uji Organoleptik}

Tabel 1. Hasil Friedman Test

\begin{tabular}{cccccc}
\hline Kode Produk & $\mathrm{N}$ & Median Rasa & Median Aroma & Median Warna & $\begin{array}{c}\text { Median } \\
\text { kenampakan }\end{array}$ \\
\hline K1P1 & 40 & 3.22 & 3.72 & 3.94 & 3.94 \\
K1P2 & 40 & 3.17 & 3.61 & 4.00 & 4.00 \\
K1P3 & 40 & 3.11 & 3.56 & 4.00 & 4.00 \\
K2P1 & 40 & 3.33 & 3.72 & 4.00 & 4.00 \\
K2P2 & 40 & 3.22 & 3.72 & 4.00 & 4.00 \\
K2P3 & 40 & 3.22 & 3.67 & 4.00 & 4.00 \\
K3P1 & 40 & 3.33 & 3.72 & 4.06 & 4.06 \\
K3P2 & 40 & 3.89 & 3.78 & 4.00 & 4.00 \\
K3P3 & 40 & 3.50 & 4.00 & 4.00 & 4.00 \\
\hline
\end{tabular}

Keterangan : rasa $(0.01<0.05)$; aroma ; $(0.028<0.05)$; warna $(0.311>0.05)$; kenampakan $(0.016<0.05)$

\section{Kesukaan Terhadap Rasa}

Tabel 1 menunjukkan bahwa susu kedelai kuning lebih disukai oleh konsumen, sedangkan susu kedelai edamame memberikan nilai kesukaan yang terendah. Berdasarkan hasil Friedman 
test, $p$ value $(0,01)<0,05$. Artinya kesembilan perlakuan memiliki pengaruh terhadap kesukaan pada rasa. Tingginya nilai kesukaan rasa susu kedelai edamame, diduga karena kandungan isoflavon dalam kacang kedelai mampu memberikan rasa pahit (bitterness) pada susu kedelai. Menurut Okubo et al. (1992), isoflavon berupa genistein dan daidzein dapat memberikan kontribusi rasa pahit yang cukup besar. Selama produksi susu, secara alami enzim $\beta$-glukosidase akan muncul dan mengubah isoflavon bentuk glukosida menjadi bentuk aglikon (daidzein dan genistein) yang rasanya lebih pahit (Matsuura et al., 1989).

Tingginya nilai kesukaan rasa pada susu kedelai kuning kemungkinan dikarenakan kandungan isoflavon dalam kedelai kuning yang lebih rendah dibandingkan dengan kedelai edamame dan kedelai hitam. Dimana pada kedelai kuning, isoflavon (genistein sebesar 0,40 $\mathrm{mg} / \mathrm{g}$; daidzein sebesar 2,27 mg/g) (Nurrahman, 2015). Menurut Bagwat et al. (2008), kedelai hitam mengandung isoflavon total sebesar $154-440 \mathrm{mg} / 100 \mathrm{~g}(154,45 \%$ per $100 \mathrm{gram})$ sedangkan kedelai edamame memiliki isoflavon sebesar $48,95 \mathrm{mg} / 100 \mathrm{~g}$ (48,95\% per $100 \mathrm{gram})$. Rendahnya nilai kesukaan rasa pada susu kedelai edamame kemungkinan dikarenakan rendahnya kandungan glutamat (berperan penting memberikan rasa gurih) pada susu kedelai. Nurrahman (2015) menyatakan bahwa kandungan glutamat pada kedelai hitam (Malika) adalah sebesar $95,11 \mathrm{mg} / \mathrm{g}$ dan kedelai kuning (Grobogan) sebesar $98,75 \mathrm{mg} / \mathrm{g}$. Sedangkan kandungan glutamat pada edamame adalah 33,4 mg/100 gram (Song et al., 2003). Hal tersebut dapat menunjukkan bahwa tidak disukainya susu kedelai edamame kemungkinan dikarenakan kurangnya rasa gurih pada susu kedelai edamame yang dihasilkan.

Perlakuan K3P2 lebih disukai panelis kemungkinan dikarenakan pada konsentrasi enzim tersebut dapat memberikan rasa yang pas yaitu tidak terlalu manis, tidak pahit dan tidak begitu langu. Pada proses hidrolisis protein, konsentrasi enzim yang digunakan harus tepat. Apabila konsentrasi enzim papain yang digunakan terlalu tinggi, maka hal ini menyebabkan rasa yang kurang diminati oleh konsumen.

\section{Kesukaan terhadap Aroma}

Berdasarkan pada Tabel 1 diketahui bahwa aroma susu kedelai kuning lebih disukai konsumen dibandingkan susu kedelai edamame dan kedelai hitam. Berdasarkan hasil Friedman test, $p$ value $(0,028)<0,05$. Artinya kesembilan perlakuan memiliki pengaruh terhadap kesukaan pada aroma. Rendahnya nilai kesukaan aroma kedelai kuning dan kedelai hitam, kemungkinan disebabkan oleh masih tersisanya bau langu (beany flavour) pada susu kedelai hitam dan edamame. Menurut Hastuti et al. (2001) dalam Wikanta et al. (2010), rasa langu tersebut disebabkan adanya asam lemak tidak jenuh terutama linoleat yang dikatalisa oleh enzim lipoksigenase. Lipoksigenase mengkatalisis reaksi oksidasi asam lemak tak jenuh menjadi asam lemak hidroperoksida. Lipoksigenase termasuk kedalam sub kelas esterase karena lipoksigenase memecah ikatan ester pada minyak (Wikanta et al., 2010). Tingginya nilai kesukaan panelis terhadap susu kedelai kuning, kemungkinan disebabkan oleh kandungan linoleat dalam kedelai kuning yang lebih rendah dibandingkan kedelai hitam dan kedelai edamame. Dimana, dengan rendahnya kandungan asam linoleat tersebut, maka asam linoleat yang dikatalisa oleh enzim lipoksigenase semakin rendah. Sehingga asam lemak hiperoksida yang terbentuk semakin sedikit, dan aroma langu yang dihasilkan terhitung rendah.

Menurut Ginting (2002), kandungan asam lemak linoleat pada kedelai hitam sebesar $1.984,92$ per 100 gram biji kedelai, pada kedelai kuning sebesar 1.792,39 per 100 gram biji kedelai dan pada kedelai edamame sebesar 44,77\% (Young dan Mebrahtu, 1998). Selain itu menurut Ginting (2002), cita rasa langu pada sari kedelai dipengaruhi juga oleh sifat genetis biji kedelai dan cara pengolahannya. Diduga jenis kedelai kuning dengan penambahan enzim papain sebesar 200 ppm lebih disukai panelis dikarenakan memiliki konsentrasi enzim papain yang pas dan memiliki aroma susu kedelai yang tidak begitu langu. 
Pengaruh Penambahan Enzim Papain - Soleha, dkk Jurnal Pangan dan Agroindustri Vol.6 No.3: 18-29, Juli 2018

\section{Kesukaan Terhadap Warna}

Berdasarkan pada Tabel 1, diketahui bahwa susu kedelai dengan jenis kedelai kuning memiliki nilai kesukaan yang lebih tinggi dibandingkan dengan susu kedelai hitam dan kedelai kuning. Hal ini kemungkinan diakibatkan oleh perbedaan warna bahan baku biji kedelai yang digunakan. Dimana, susu kedelai edamame memiliki warna hijau, susu kedelai hitam berwarna putih tulang dan susu kedelai kuning memiliki warna kuring cerah hampir mendekati warna putih. Kesukaan konsumen terhadap susu kedelai kuning, kemungkinan disebabkan karena susu kedelai kuning lebih menyerupai warna susu pada umumnya.

Berdasarkan Friedman test dihasilkan $p$ value $(0,311)>0,05$. Artinya kesembilan perlakuan tidak memiliki pengaruh signifikan terhadap kesukaan pada warna. Diduga susu kedelai kuning dengan penambahan enzim papain 100 ppm (K3P1) lebih disukai panelis, dikarenakan susu kedelai kuning memiliki warna yang cenderung lebih cerah dan lebih diterima oleh konsumen dibandingkan perlakuan lainnya. Berdasarkan data warna didapatkan tingkat kecerahan (L) pada kedelai kuning dengan penambahan enzim papain sebesar 100 ppm menduduki posisi tertinggi yaitu 80,27 . Tingginya nilai kecerahan tersebut menyebabkan susu kedelai jenis kedelai kuning dengan penambahan enzim papain 100 ppm lebih memberikan nilai kesukaan yang lebih tinggi dibandingkan perlakuan lainnya. Hal ini diduga terjadinya reaksi Maillard saat proses hidrolisis enzimatis berlangsung. Reaksi Maillard dimungkinkan terjadi pada saat berlangsungnya proses hidrolisis dengan panas, dimana rangkaian proses reaksi tersebut diakhiri dengan terbentuknya senyawa melanoidin yang berwana kecoklatan (De Man, 1999).

\section{Kesukaan Terhadap Kenampakan}

Berdasarkan pada Tabel 1, diketahui bahwa yang memberikan nilai kesukaan tertinggi terhadap kenampakan produk susu kedelai kuning dengan konsentrasi enzim papain sebesar 100 ppm, dan perlakuan kedelai hitam dengan konsentrasi enzim papain 200 ppm memberikan nilai terendah. Berdasarkan hasil penelitian didapatkan $p$ value $(0,016)<0,05$. Artinya kesembilan perlakuan memiliki pengaruh signifikan terhadap kesukaan pada kenampakan. Diketahui pula bahwa susu kedelai kuning lebih diminati dalam hal kenampakan karena memberikan nilai tertinggi. Kenampakan sangat erat kaitannya dengan warna produk. Lebih diminatinya kenampakan susu kedelai kuning, kemungkinan dikarenakan susu kedelai kuning memiliki warna yang lebih disukai oleh konsumen dan juga memiliki kenampakan susu yang lebih homogen dibandingkan dengan susu kedelai hitam yang memiliki warna lebih gelap serta susu edamame yang memiliki warna hijau.

Pada kedelai kuning dengan penambahan enzim papain sebesar 300 ppm memiliki kenampakan yang cukup diminati dan tidak terjadi pemisahan. Sedangkan pada kedelai hitam cenderung memiliki kenampakan yang kurang diminati yaitu cenderung tidak homogen. Tidak homogennya sampel yang disediakan diduga selama pengolahan dan penyimpanan susu kedelai terjadi pemisahan susu. Selain itu, diduga kecepatan dan lama pengadukan susu kedelai saat setelah penambahan BTM (Bahan Tambahan Makanan) kurang tinggi dan kurang lama. Sehingga pengadukan bahan bahan yang ditambahkan (gula, garam, CMC) kurang efektif. Selain pengadukan, faktor penting lainnya adalah penambahan emulsifier, pada penelitian ini hanya dilakukan penambahan stabilizer yaitu CMC, sedangkan pada pembuatan susu kedelai diperlukan adanya emulsifier agar tidak terjadi pemisahan susu kedelai setelah penyimpanan.

\section{SIMPULAN}

Berdasarkan karakteristik kimia dan fisik, susu kedelai yang terbaik adalah perlakuan K2P3 yaitu susu kedelai hitam dengan konsentrasi enzim papain $300 \mathrm{ppm}$. Nilai protein terlarut 0,34 \%; N Amino 0,02\%; pH 6,6; viskositas 5,00; kecerahan (L) 77,1; kehijauan (a-) -3.4 dan kekuningan (b) 14,3. Berdasarkan karakteristik organoleptik, susu kedelai yang terbaik adalah perlakuan K3P2 yaitu susu kedelai kuning dengan konsentrasi enzim papain 200 ppm. Nilai kesukaan 
Pengaruh Penambahan Enzim Papain - Soleha, dkk Jurnal Pangan dan Agroindustri Vol.6 No.3: 18-29, Juli 2018

terhadap rasa sebesar 3.88, kesukaan terhadap aroma sebesar 3,63; kesukaan terhadap warna sebesar 3,93 dan kesukaan terhadap kenampakan sebesar 3,80.

\section{DAFTAR PUSTAKA}

Agustawa, R. 2012. Modifikasi Pati Ubi Jalar (Ipomea batatas L.) Varietas Sukuh dengn proses Fermentasi dan Metode Heat Moisture Treatment (HMT) terhadap Karakteristik Fisik dan Kimia Pati. Skripsi. Universitas Brawijaya. Malang.

Almatsier, S. 2009. Prinsip Dasar IImu Gizi. PT. Gramedia Pustaka Utama. Jakarta.

Deliana. 2008. Pengaruh Lama Fermentasi terhadap Kadar Protein, Lemak, Komposisi Asam Lemak dan Asam Fitat pada Pembuatan Tempe. Disertasi. Universitas Sumatera Utara. Medan.

De Man, J.M. 1999. Principles of Food Chemistry. 3rd. Ed. Springer International Publishing Maryland.

Ginting, E., dan Antarlina S.S. 2002. Pengaruh Varietas dan Cara Pengolahan Terhadap Mutu Susu Kedelai. Jurnal Tanaman Pangan 21: 2, 48-57.

Ginting, E. dan Adie, M.M. 2007. Sifat Fisik dan Kimia Lima Galur Kedelai Hitam Serta Kualitas Kecap yang Dihasilkan. dalam Harnowo D., Rahmianna S.A.A., Adie M.M., Rozi F., Subandi, dan Makarim A.K. (Ed.). Peningkatan Produksi Kacang-Kacangan dan UmbiUmbian Mendukung Kemandirian Pangan. Pusat Penelitian dan Pengembangan Tanaman Pangan, Bogor.

Hasibuan, A. S. D. 2011. Pengaruh Suhu Air Pendinginan PLTU terhadap Kandungan Klorofil Pada Air Sungai Sicanang Belawan. Skipsi (Online), http://repository.usu.ac.id. Tanggal akses: 11/06/2017.

Hastuti. 2001. dalam Wikanta. D.K., Yulianto, M.E., Hartati, I. 2010. Kajian Model Matematis Kinetika Inaktivasi Enzim Lipoksigenase untuk Produksi Tepung Biji Kecipir sebagai Tepung Komposit. Momentum 6: 1, 21-26.

Kementerian Pertanian. 2015. Outlook Komoditas Pertanian Subsektor Tanaman Pangan. ISSN 19071507.

Lehninger, A. L. 1994. Dasar-dasar Biokimia. Terjemahan: Maggy Thenawijaya. Penerbit Erlangga, Jakarta.

Maryam, S. 2007. Penentuan Suhu Optimum Pada Saat Menggiling Kedelai untuk Menghasilkan Tahu Berkualitas. JPPSH, hal. 157.

Matsuura, M., Obata, A., and Fukushima, D. 1989. Objectionable Flavor of Soymilk Developed During the Soaking of Soybean and its Control. J. Food Sci. 54: 3, 602-605.

Nielsen, S. 2010. Food Analysis. Fourth Edition. Springer. USA.

Nurrahman. 2015. Evaluasi Komposisi Zat Gizi dan Senyawa Antioksidan Kedelai Hitam dan Kedelai Kuning. Jurnal Aplikasi Teknologi Pangan 4: 3, 89-93.

Okubo, K., lijima M., Kobayashi Y., Yoshikoshi M., Uchida T., and Kudou S. 1992. Components Responsible for The Undesirable Taste of Soybean Seeds. Biosci. Biotech. Biochem. 56: 1, 99-103.

Sofyanti, S. 2007. Pengaruh Konsentrasi Penstabil dan Konsentrasi Flavour (Bubuk Cokelat) terhadap Mikrokristal Sari Kedelai (Glycine max (L.) Merril). Skripsi. Universitas Pasundan. Bandung.

Song, J., An G.H., and Kim C.J. 2003. Color, Texture, Nutrient Contents, and Sensory Values of Vegetable Soybean (Glycine Max (L). Merill) as Affected by Blanching. Food Chemistry 83: $1,69-74$.

Sudarmadji, S., Haryono, B., dan Suhardi. 1997. Analisis Bahan Makanan dan Pertanian. Edisi Keempat. Liberty. Yogyakarta. 
Sumartha, I.G.1990. Oryza. dalam Kusumadjaja, A.P., dan Dewi, R.P. 2005. Penentuan Kondisi Optimum Enzim Papain dari Pepaya Burung Varietas Jawa (Carica papaya). Indonesian Journal of Chemistry. 5: 2,147-151.

United States Depatement of Agriculture (USDA). 2016. Nutrient Database of Standard Reference. https://ndb.nal.usda.gov/ndb/foods/show/. Tanggal akses: 25/06/2016.

Wijaya, J.C., dan Yunianta. 2015. Pengaruh Penambahan Enzim Bromelin terhadap Sifat Kimia dan Organoleptik Tempe Gembus (Kajian Konsentrasi dan Lama Inkubasi dengan Enzim). Jurnal Pangan dan Agroindustri 3: 1, 96-106.

Wikanta, D.K., Yulianto M. E., dan Hartati I. 2010. Kajian Model Matematis Kinetika Inaktivasi Enzim Lipoksigenase untuk Produksi Tepung Biji Kecipir sebagai Tepung Komposit. Momentum 6: 1, 21-26.

Witono, Y., Subagio, A., dan Widjanarko, S.B. 2007. Karakterisasi Hidrolisat Protein Kedelai Hasil Hidrolisis Menggunakan Protease dari Tanaman Biduri (Calotropis gigantae). Berk. Penelitian Hayati $13: 7$ - 13.

Young, G., and Mebrahtu, Y. 1998. Protein, Fiber, and Lipid Content of Vegetable Soybean. Journal of the American Dietetic Association 98: 9, A44.

Yulifianti, R., Ginting, E., dan Sundari T. 2015. Karakteristik Tahu dari Kedelai Varietas Toleran Naungan Dena 2. Prosiding Seminar Hasil Penelitian Tanaman Aneka Kacang dan Umbi 2.

Yuwono, S., dan Susanto, T. 2001. Pengujian Fisik Pangan. Fakultas Teknologi Pertanian. Universitas Brawijaya. Malang. 